\title{
Jurnal Teknologi Pendidikan
}

http://journal.unj.ac.id/unj/index.php/jtp

Vol. 21, No. 2, Agustus 2019

\section{Pengembangan Mobile Learning IPA Sasirangan Materi Pencemaran Lingkungan untuk Peserta Didik SMP}

Info Artikel

Sejarah Artikel:

Diterima: 15 Juni 2019

Direvisi: 15 Juli 2019

Dipublikasikan: Agustus 2019

e-ISSN: 2620-3081

p-ISSN: 1411-2744

DOI: https://doi.org/ $\underline{10.21009 / \text { itp.v21i2.11446 }}$

\author{
Putri Diana Amrita ${ }^{1}$, Heru Kuswanto ${ }^{2}$
}

\begin{abstract}
This study is aimed at: (1) creating Sasirangan Science Mobile (MLI Sasirangan) Learning product for junior high school students and (2) exemaining the feasibility level of MLI Sasirangan according to experts, practitioners, academics, and the response of. The type of this research is research and development $(R \& D)$ that use $4 D$ model consisting of define, design, develop and disseminate stage. Furthermore, the result of this research shows that: (1) Android-web-application-based MLI Sasirangan was created from Learning Management System (LMS) Moodle; (2) based on the assessment result from media and material experts, this product obtained a value of 4.73 and 4.39. Meanwhile, the evaluation result from practitioners and peers, the values obtained were 4.45 and 4.64. Moreover, from the limited trial test, this product obtained a value of 4.47. Therefore, it can be concluded that MLI Sasirangan which has been developed is considered feasible with very good criteria to be used as science learning media.
\end{abstract}

Keywords: mobile learning, android, sasirangan, science

\begin{abstract}
Abstrak: Penelitian ini bertujuan untuk: (1) menghasilkan produk Mobile Learning IPA (MLI) Sasirangan untuk peserta didik SMP; (2) menguji tingkat kelayakan MLI Sasirangan menurut para ahli, praktisi, akademisi dan respon peserta didik. Jenis penelitian adalah penelitian dan pengembangan $(R \& D)$ mengunakan model $4 D$ yang terdiri atas tahapan pendefinisian (define), perancangan (design), pengembangan (develop) dan penyebarluasan (dessiminate). Penelitian menunjukkan hasil sebagai berikut: (1) MLI Sasirangan berbasis aplikasi android dibuat dari Learning Management System (LMS) moodle; (2) hasil penilaian ahli media dan materi dengan nilai 4.73 dan 4.39. Hasil penilaian oleh praktisi dan teman sejawat diperoleh nilai 4.45 dan 4.64. Hasil uji coba dengan nilai 4.47. Dapat disimpulkan bahwa produk MLI Sasirangan yang dikembangkan layak dengan kriteria sangat baik untuk digunakan pada pembelajaran IPA.
\end{abstract}

Kata kunci: mobile learning, android, sasirangan, IPA

\footnotetext{
${ }^{1}$ Mahasiswa Program Studi Pendidikan Sains, PPs Universitas Negeri Yogyakarta, Kampus Karang malang, Sleman DIY 55281, putridianaamrita.2017@ student.uny.ac.id, +6282298473234

2 Dosen Program Studi Pendidika Fisika, Fakultas Matematika dan IPA, Universitas Negeri Yogyakarta, Kampus Karangmalang, Sleman DIY 55281
} 


\section{PENDAHULUAN}

$21^{\text {st }}$ Century Skill atau Keterampilan abad21 memiliki tujuan mempersiapkan peserta didik agar dapat berkompetensi dalam masyarakat global (Pernia, 2008). Keterampilan ini menitikberatkan pada capaian 3 ranah kompetensi yang terdiri atas kompetensi kognitif (learning and innovation skill), kompetensi interpersonal (information, media and technology skill) serta kompetensi intrapersonal (life and career skill) (Tan et al., 2017). Capaian tersebut juga sejalan dengan prinsip pembelajaran pada kurikulum 2013 sehingga sangat memungkinkan untuk dilatihkan dan dikembangkan di kelas. Sebagian diantaranya terdiri dari prinsip pembelajaran yang lebih menekankan pada keterampilan aplikatif, meningkatkan dan menyeimbangkan antara keterampilan fisik dan mental, penerapan nilainilai dan kreativitas peserta didik serta pemanfaatan TIK untuk meningkatkan efisiensi dan efektivitas pembelajaran. Jadi, pembelajaran saat ini lebih ditekankan kepada pemanfaatakan teknologi, pengembangan keterampilan berpikir dan menumbuhkan nilai-nilai keteladanan, kecakapan hidup yang dapat diterapkan dalam masyarakat saat ini hingga beberapa dekade mendatang.

Pelaksanaan pembelajaran IPA di sekolah diharapkan dapat dijalankan melalui pengamatan, penemuan dan penyelidikan sesuai dengan model pembelajaran yang direkomendasikan pemerintah untuk pelaksanaan kurikulum 2013. Keterpaduan pembelajaran IPA dengan lingkungan sekitar peserta didik dapat melatihkan keterampilan berpikir, sikap peduli dan bertanggung jawab terhadap lingkungan alam. (Cahyaningrum \& Parmin, 2013). Strategi pembelajaran IPA diharapkan lebih mengedepankan lingkungan sebagai sumber belajar (kontekstual) dan memberikan pengalaman belajar yang bermakna (Priya, 2018).

Laporan mengenai pemanfaatan TIK dari UNESCO Institute for Statiss tentang ICT dalam pendidikan di Asia ditemukan bahwa pemanfaatan TIK yang diintegariskan pada pembelajaran masih tergolong dalam kategori rendah (1-5 jam pelajaran/minggu) (Wallet, 2014). Dari segi kemampuan kognitif, kemampuan IPA peserta didik Indonesia memang masih berada di bawah rata-rata berdasarkan data dari Trend In International Mathematics And Science Study (TIMSS) yang dilinisiasi oleh The International Assiciation For The Evaluation Of Educational Achievment (IEA) (2015) diketahui siswa SMP kelas 8 Indonesia berada dalam peringkat 45/68 dengan poin 397. Dimana penilaian dilakukan dalam tiga domain kognitif yaitu mengetahui (knowing), bernalar (reasoning), dan aplikasi (applying) (Kemdikbud, 2015).

Salah satu cara yang dapat digunakan untuk mengatasi permasalahan di atas yaitu dengan memanfaatkan peranan teknologi untuk pembelajaran IPA dengan memasukkan konten terkait lingkungan sekitar peserta didik. Dengan memanfaatkan perangkat seluler (mobile) sebagai perangkat teknologi, peserta didik dapat mempelajari konsep secara lebih nyata dan kontektual sehingga dapat merangsang keterampilan berpikir serta menamkan nilai-nilai ketauladanan dari pembelajaran yang dilakukan. Seperti yang diungkapkan oleh Ligi dan Raja (2017) bahwa M-learning sebagai salah satu penerapan dari proses pembelajaran dan pendidikan yang diintegrasikan dengan TIK terbaru pada sistem pendidikan. 
Teknologi mobile atau tablet yang dibuat dalam bentuk aplikasi mobile (mobile app) memberikan hasil yang positf kepada peserta didik. Hal ini sesuai dengan pendapat Klimova (2019), di mana aplikasi mobile yang dirancang sesuai dengan kebutuhan peserta didik dan difasilitasi secara terus-menerus oleh guru efektif dalam meningkatkan kinerja dan kontribusi yang positif pada hasi belajar peserta didik. Motivasi peserta didik ketika memanfaatkan aplikasi pembelajaran pada smartphone mengarah pada partisipasi yang lebih besar sehingga lebih baik dan lebih cepat memperoleh konsep atau keterampilan. Sehingga, hal ini dapat dilakukan sebagai upaya untuk meningkatkan efesiensi dan efektivitas pembelajaran (Ferreira et al., 2015).

\section{Mobie Learning}

M-learning menyediakan konten dan sumber daya pedidikan yang dimuat dalam perangkat saku seperti smartphone, tablet, PDA, i-pad dan mobile phone dan perangkat sejenis. Konten penddikan mengacu pada sumber belajar digital yang mencakup segala bentuk atau format konten yang dapat tersedia dalam perangkat pribadi (personal device) (Ligi \& Raja, 2017). Penerapan M-learning melibatakan tiga komponen yang terdiri dari perangkat mobile, sofware dan konten pembelajaran (Martono Kurniawan \& Nurhayati Oky, 2014). Kemudian, Gnana Singh et al. (2017) mengungkapkan perangkat mobile terdiri atas komponen perangkat keras (hardware) dan perangkat lunak (software). Komponen software dalam m-learning diklasifikasikan sebagai sistem operasi mobile (Mobile Operating System/Mobile OS) dan aplikasi mobile (mobile app ). Aplikasi mobile terbagi dapat terdiri atas native app, web-based app dan hybrid app. Native app dibuat dan dikomplikasi menggunakan bahasa pemrogaman tertentu untuk masing-masing jenis mobile OS. web-based app dibuat dengan bahasa web (misalnya .HTML, CSS, Javascript dan AJAX) dan dapat ditafsirkan melalui browser web pada perangkat mobile. Sedangkan, hybrid app merupakan gabungan antara native app dan web-based app (Holzer \& Ondrus, 2011).

Merujuk pada web-based app dari mobile application, maka pengembangan m-learning juga dapat memanfaatkan Learning Management System (LMS) berbasis web dengan platform yang bervariasi. Secara umum, LMS menyediakan beberapa fasilitas diantaranya Alat keterampilan belajar (learnng skill tools) yang berfungsi untuk menyediakan aktivitas dan perlengkapan pembelajaran. seperti kuis,ujian atau tes, presentasi, penugasan; alat komunikasi (communication tools) yang berfungsi untuk menfasilitasi interaksi antara guru dengan peserta didik serta peserta didik dengan sesama peserta didik. misalnya penguguman, diskusi, forum, chat, teleconference, berbagi dokumen, transfer file, dan lain-lain; Alat produktvitas (productivity tools) yang berfungsi untuk menfasilitasi sistem pengaturan dokumen pembelajaran (document file dan media file), termasuk didalamnya fitur uploading dan downloading documents, penyimpanan data peserta didik dan aktivitas kuis, tes dan penugasan (Kasim \& Khalid, 2016). Moodle merupakan slah satu jenis LMS yang paling banyak digunakan. Moodle (modular object oriented dynamic learning evironment) merupakan LMS open source yang mulai dikembangkan tahun 2001 dan didasarkan pada prinsip pedagogis konstruksi sosial. 
LMS ini dikembangkan di bawah GNU General Public Lisence (GPL) yang berarti setiap perubahan dapat dilakukan ke kode sumber selama lisensi asli tidak diubah. Moodle didukung oleh bahasa inggris namun dapat pula didukung oleh bahasa berbeda dari 235 negara, termasuk Bahasa Indonesia dengan jumlah pengguna lebih dari 17 juta orang pada tahun 2008 (Mohammed, 2017).

Android OS, Blackberry OS, iPhone dan lain-lain merupakan contoh dari mobile Operating System (OS) (Gnana Singh et al., 2017). Sistem operasi tersebut dapat digunakan untuk menjalankan aplikasi mobile sesuai dengan karakterisrik masing-masing. Salah satu sistem operasi yang ada yaitu Android OS memiliki basis linux. Android menyediakan platform terbuka bagi pengembang untuk membuat aplikasi mereka sendiri untuk dapat digunakan pada perangkat yang beragam (Martono Kurniawan \& Nurhayati Oky, 2014).

M-learning dapat menyediakan bahan ajar yang dapat membantu pelajar mengakses materi pembelajaran dalam berbagai bentuk format (Elkhateeb et al., 2019). M-learning berbentuk mobile app yang mendukung isi bahan ajar online dapat disesuaikan dengan bahan ajar konvensional (paperbased). Adapun bagian-bagian dari bahan ajar paling tidak mencakup petunjuk belajar, kompetensi yang akan dicapai, konten dan isi pembelajaran, informasi pendukung, latihan-latihan, petunjuk kerja dapat berupa lembar kerja (worksheet), evaluasi, respon peserta didik (feedback) (Darnita, K. et al., 2014).

\section{Karakteristik Pembelajaran IPA dan Sasirangan}

Karakteristik pembelajaran IPA atau Natural Science berkaitan dengan perolehan pengetahuan dari hasil penyelidikan ilmuan melalui pengamatan, klarifikasi data, disusun dan diverifiksi yang melibatkan penalaran matematis dan analisis data terhadap gejala-gejala alam (Djojosediro, 2010).

Materi pencemaran lingkungan memiliki cakupan yang cukup luas karena peserta didik akan sangat mudah menemukan contoh pencemaran dalam kehidupan sehari-hari mereka, seperti di lingkungan tempat tinggal dan sekolah. Sub pokok materi ini sendiri terdiri dari jenis-jenis pencemaran, penyebab dan dampak pencemaran dari limbah-limbah diberbagai bidang kehidupan serta cara-cara untuk menanggulangi atau mengurangi penyebaran pencemaran. Penyebab pencemaran yang sering menjadi sorotan baik oleh Badan lingkungan hidup (BLH) dan masyarakat yaitu pencemaran yang disebabkan dari limbah industri. Salah satunya adalah pada industri pembuatan kain sasirangan, kain khas dari daerah Kalimantan Selatan.

Kain sasirangan merupakan kain adat suku banjar yang ada di daerah Kalimantan Selatan,. Proses pembuatan kain sasirangan menggunakan teknik jahit jelujur (menyirang) kain putih menggunakan jarum jeans disertai penarikan dan pengikatan benang perintang melalui pemanasan dengan zat pewarna menggunakan zat pewarna sintetis. Zat warna indigosol yang merupakan garam natrium dari ester indigo disulfat atau zat warna bejana jenis antrakuonin (Murwati et al., 2012).

Kegiatan industri rumah tangga kerajinan sasirangan khususnya di Kampung Sasirangan Banjarmasin berpotensi menimbulkan pencemaran lingkungan dalam tahapan proses pewarnaan, 
pengrajin masih menggunakan pewarna sintetis apabila tidak ditangani dengan baik. Limbah langsung dibuang ke sungai tanpa dilakukan pengolahan terlebih dahulu. Akibat pembuangan limbah cair hasil pewarnaan sungai menjadi berwana dan menimbulkan rasa gatal jika airnya digunakan untuk mandi pada titik tertentu di pesisir sungai (Nurdiansyah, 2013; Rachman, H. et al., 2017)

Mobile learning dirancang untuk memuat media gambar dan video yang menggambarkan situasi nyata untuk membelajarkan konsep IPA yang dikaitkan dengan lingkugan lokal ini. Hal ini sejalan dengan pendapat Kurniawati et al. (2017) bahwa media interaktif yang memuat gambar dapat meningkatkan keterampilan afektif, psikomotorik dan kemampuan kognitif. Peserta didik termotivasi untuk belajar karena penggunaan media pembelajaran yang interaktif dan diaplikasikan dalam pengalaman dan situasi pembelajar dalam pembelajaran yang nyata (Kurniawati et al., 2017).

Berdasarkan kajian mengenai pengembangan bahan ajar online yang mengangkat isu lingkungan lokal dari pembuatan kain sasirangan (khas kalimantan selatan) ini maka rumusan masalah yang ditetapkan adalah sebagai berikut: (1) bagaimana produk Mobile Leraning IPA Sasirangan materi pencemaran lingkungan dihasilkan?; (2) bagaimana kelayakan Mobile Leraning IPA Sasirangan materi pencemaran lingkungan menurut para ahli, praktisi, akademisi dan uji coba terbatas terhadap peserta didik?

Adapun manfaat yang diperoleh dalam penelitian ini yaitu bagi sekolah dan guru sebagai sumber rujukan untuk mengembangkan mobile app berisi bahan ajar online yang memuat materi IPA terintegrasi dengan potensi pencemaran lingkungan dari pembuatan kain sasiangan di Kalimantan Selatan.

\section{METODE}

Penelitian ini merupakan penelitian pengembangan atau Research and Development $(R \& D)$ yang mulai dilaksanakan pada bulan September 2018 di Yogyakarta dan Banjarmasin. Penelitian ini bertujuan untuk mengembangkan dan menghasilkan mobile learning IPA terintegrasi lingkungan lokal pembuatan kain sasirangan. Penelitian ini menggunakan model pengembangan 4D yang terdiri dari tahapan: pendefinisian (define), perancangan (design), pengembangan (development) dan penyebarluasan (dessiminate) (Tihiagarajan \& Semmel, 1974). Penjelasan untuk masing-maisng tahapan penelitian dan pengembangan adalah sebagai berikut.

Tahap pendefinisian (define) yang terdiri dari tahapan-tahapan analisis awal (studi pendahuluan), analisis peserta didik, analisis konsep, analisis tugas dan perumusan tujuan pembelajaran.

Tahap perancangan (design) yang terdiri dari tahapan penyusunan tes acuan kriteria, pemilihan media, pemilihan format dan perancangan awal produk.

Tahap pengembangan (develop), yang merupakan tahapan yang dilakukan untuk menghasilkan produk yang layak setelah dilakukan penilaian oleh ahli yang terdiri dari ahli dosen Pendidikan IPA (materi dan media), guru IPA dan teman sejawat yaitu mahasiswa program 
pascasarjana Pendidikan IPA (akademisi). Selanjutnya, uji coba terbatas produk dilakukan kepada 9 orang peserta didik kelas VII SMPN 1 Banjarmasin yang telah mempelajari materi pencemaran lingkungan.

Tahap penyebarluasan (dessiminate), merupakan tahap akhir dari penelitian pengembangan setelah melalui proses revisi maka produk siap untuk disebarluaskan dalam bentuk aplikasi mobile learning kebeberapa SMP di Banjarmasin. Proses penyebaran juga dilakukan melalui penulisan jurnal/artikel ilmiah dan seminar/konferensi.

Instrumen yang digunakan terdiri dari angket kepemilikan smartphone, angket penilaian mobile learning IPA untuk ahli, guru IPA, teman sejawat dan angket keterbacaan untuk peserta didik. Teknik analisis yang digunakan yaitu analisis data deskriptif kualitatif. Kelayakan produk dinyatakan oleh ahli media, materi dan praktisi dinyatakan dengan rumus dan kriteria yang terdapat pada Tabel 1.

Tabel 1. Kriteria penilaian kelayakan produk

\begin{tabular}{clcc}
\hline No. & \multicolumn{1}{c}{ Rumus Rentang Skor } & Rentang Skor & Kriteria \\
\hline 1. & $\mathrm{X}>\mathrm{xi}+1,80 \mathrm{Sbi}$ & $\mathrm{X}>4,21$ & Sangat Baik \\
\hline 2. & $\mathrm{xi}+0,60 \mathrm{SBi}<\mathrm{X} \leq \mathrm{xi}+1,80 \mathrm{Sbi}$ & $3,40<\mathrm{X} \leq 4,21$ & Baik \\
\hline 3. & $\mathrm{xi}-0,60 \mathrm{SBi}<\mathrm{X} \leq \mathrm{xi}+0,60 \mathrm{Sbi}$ & $2,60<\mathrm{X} \leq 3,40$ & Cukup \\
\hline 4. & $\mathrm{xi}-1,80 \mathrm{SBi}<\mathrm{X} \leq \mathrm{xi}-0,60 \mathrm{Sbi}$ & $1,79<\mathrm{X} \leq 2,60$ & Kurang \\
\hline 5. & $\mathrm{X} \leq \mathrm{xi}-1,80 \mathrm{Sbi}$ & $\mathrm{X} \leq 1,79$ & Sangat kurang \\
\hline
\end{tabular}

\section{Keterangan:}

Diadaptasi dari Widoyoko (2009)

$\mathrm{X}=$ skor yang diperoleh $=$ Jumlah skor hasil penilaian per aspek penilaian

$\mathrm{xi}=$ rata-rata skor ideal $=(1 / 2 *($ skor ideal tertinggi dalam komponen + skor ideal terendah $)$

Sbi $=$ Simpangan baku skor ideal $=(1 / 6 *($ skor ideal tertinggi dalam komponen - skor ideal terendah dalam

komponen)

\section{HASIL DAN PEMBAHASAN}

\section{HASIL}

\section{Tahap Pendefinisian}

Pada tahap ini dilakukan studi pendahuluan melalui kajian teoritis yang diperoleh dari kajian hasil survei dan laporan hasil penelitian dilakukan terkait pemanfaatan perangkan TIK khususnya dalam hal ini penggunaan perangkat mobile dalam pembelajaran dan penyampaian konten pembelajaran yang dikaitkan dengan permasalahan lingkungan lokal yang dekat dengan peserta didik khusunya di SMP N 1 Banjarmasin yang masih berada dalam satu kecamatan dengan sentral pembuatan kain sasirangan di Banjarmasin. Analisis konsep dilakukan dengan cara menetapkan sub materi pokok bahasan pencemaran lingkungan untuk kelas VII Semester 2 Kurikulum 2013 yang akan dikaitkan dengan potensi pencemaran dari pembuatan kain sasirangan. Analisis tugas dilakukan dengan menentukan indikator pencapaian kompetensi dan tujuan pembelajaran untuk Kompetensi Dasar (KD) yang terdiri atas KD 3.8 yaitu menganalisis terjadinya pencemaran lingkungan dan dampaknya terhadap ekosistem serta KD 4.8 yaitu membuat tulisan tentang gagasan penyelesaian 
masalah pencemaran di lingkungannya berdasarkan hasil pengamatan. Analisis peserta didik untuk mengetahui kepemilikan smartphone dan aktivitas dalam penggunaan smartphone dengan menyebarkan angket kepemlikan smartphone kepada peserta didik kelas VII untuk mengetahui jenis mobile $O S$ yang paling banyak dimiliki peserta didik dan jenis akivitas yang paling diminati peserta didik.

\section{Tahap Perancangan}

Pada tahap penyusunan tes acuan kriteria sehingga dihasilkan kisi-kisi penilaian mobile learning yang terdiri atas aspek-aspek dalam unsur media dan materi. Kemudian pemilihan media dilakukan dengan cara menentukan beberapa jenis media yang terdiri dari tulisan (teks), gambar, video, link website dan file tulisan $(p d f)$ yang dapat diakses peserta didik secara personal. Pemilihan format dilakukan dengan menentukan menu-menu dalam mobile learning IPA yang diberi nama "MLI Sasirangan" disesuaikan dengan komponen bahan ajar serta perancangan produk awal yang digambarkan melalui storyboard untuk mengetahui susunan dari menu-menu yang telah ditentukan. Rancangan bahan ajar online yang dimuat dalam mobile learning IPA sasirangan seperti yang terlihat pada Tabel 1.

Tabel 1. Format dan menu-menu pada Mobile Learning IPA Sasirangan

\begin{tabular}{|c|c|c|}
\hline No. & Format Bahan Ajar & Menu mobile learning dengan moodle \\
\hline 1. & $\begin{array}{l}\text { a. Judul } \\
\text { b. Kelas } \\
\text { c. Semester } \\
\text { d. Petunjuk Belajar } \\
\text { e. Referensi (daftar Pustaka) } \\
\text { f. Identitas Penyusun }\end{array}$ & $\begin{array}{l}\text { 1) Menu Beranda (homepage) yang terdiri dari sub menu: } \\
\text { a) Deskripsi produk } \\
\text { b) Petunjuk penggunaan (MLI Sasirangan) } \\
\text { c) Sekilas tentang Sasirangan } \\
\text { d) Daftar pustaka } \\
\text { e) Penyusun }\end{array}$ \\
\hline 2. & $\begin{array}{l}\text { g. Kompetensi } \\
\text { h. Tujuan pembelajaran }\end{array}$ & $\begin{array}{l}\text { 2) Menu Kompetensi berisi: } \\
\text { a) Kompetensi Inti (KI) } \\
\text { b) Kompetensi Dasar (KD) } \\
\text { c) Tujuan Pembelajaran }\end{array}$ \\
\hline 3. & $\begin{array}{ll}\text { a. Konten Pembelajaran } \\
\text { i. Latihan/latihan dan lembar } \\
\text { kerja }\end{array}$ & $\begin{array}{l}\text { 3) Menu Apersepsi } \\
\text { 4) Menu Materi } \\
\text { 5) Menu Referensi (link web informasi tambahan) } \\
\text { 6) Menu Kegiatan } \\
\text { a) Explore 1: Ayo Mencoba: } \\
\text { b) Explore 2: Ayo Cari Tahu } \\
\text { c) Explore 3: Ayo Tulis Informasi } \\
\text { d) Explore 4: Ayo Tulis Referensi } \\
\text { e) Explore 5: Ayo Tambah Informasi } \\
\end{array}$ \\
\hline 4. & j. Tes (Sumatif) & f) Ayo Cek Pemahaman \\
\hline 5 . & k. Respon peserta didik & 7) Menu Massege \\
\hline
\end{tabular}

\section{Tahap Pengembangan}

Pengembangan produk MLI Sasirangan dibuat menggunakan Learning Management System (LMS) Moddle yang merupakan jenis hybrid app (gabungan native dan web-based app). Pembuatan MLI sasirangan terdiri dari tahapan membuat portal e-learning (web) dengan moodle, menentukan tema, memasukkan media menconvert web ke dalam bentuk aplikasi android untuk dapat dijalankan 
secara terpisah dari browser dan membuat akun user (pengguna). Tampilan mobile learning IPA sasirangan seperti yang terlihat pada gambar 1 .

\section{Kelayakan MLI Sasirangan}

Pada tahap pengembangan juga dilakukan uji validasi dari aplikasi yang telah dikembangkan. Penilaian dilakukan oleh masing-masing seorang dosen pengampu mata kuliah teknologi pembelajaran untuk menilai kualitas produk dan kinerja MLI Sasirangan serta dosen pengampu mata kuliah ilmu lingkungan untuk menilai materi pencemaran lingkungan yang diintegrasikan dengan limbah pembuatan kain sasirangan. Hasil validasi MLI sasirangan seperti yang terdapat pada Tabel 3 dan 4.
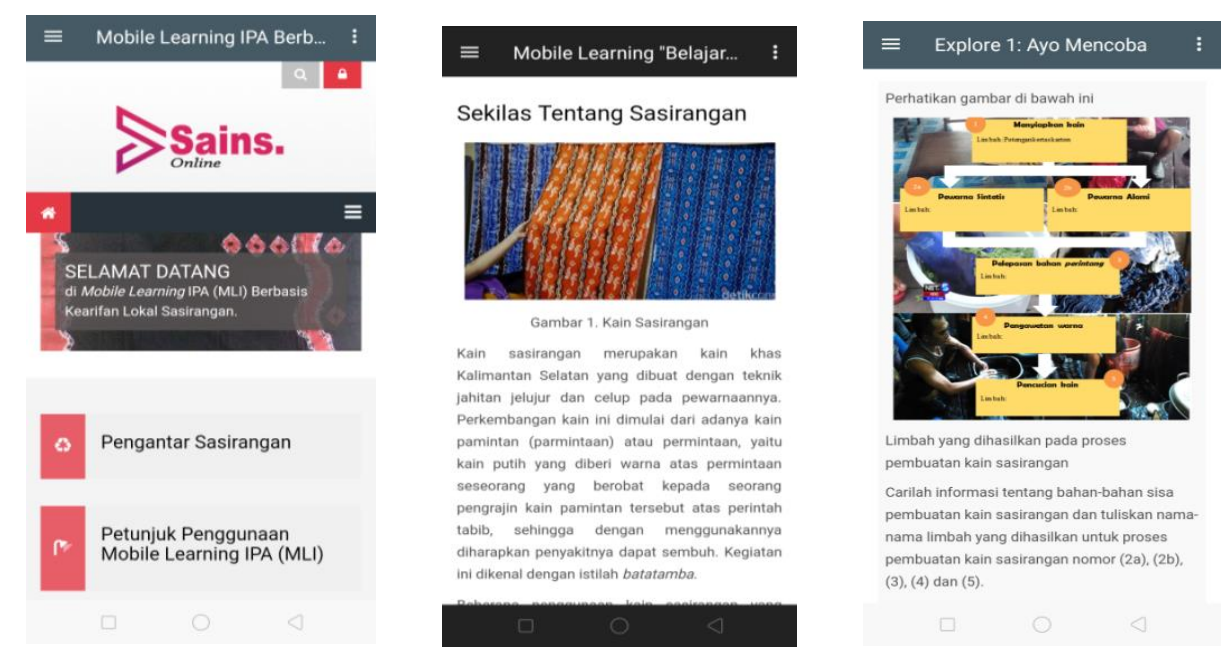

Gambar 1a, 1b, 1c

Tampilan (1a) Beranda, (1b) Informasi mengenai kain sasirangan, (1c) Salah satu kegiatan dalam MLI sasirangan

Tabel 3. Hasil Validasi Mobile Learning Sasirangan oleh Ahli Media

\begin{tabular}{|c|c|c|c|}
\hline No. & Aspek Penilaian & Indikator & Skor \\
\hline \multirow[t]{5}{*}{1.} & Tampilan antarmuka & Kesesuaian tema, icon dan teks pada homepage & 4,00 \\
\hline & & Kesesuaian tata letak (layout) & 4,00 \\
\hline & & Kualitas media (gambar, video, link dan file document) & 3,00 \\
\hline & & Kualitas teks (tulisan) & 5,00 \\
\hline & & Konsistensi navigasi dan spasi & 5,00 \\
\hline 2. & Kehandalan & Kemudahan pengoperasian program & 5,00 \\
\hline \multirow[t]{4}{*}{3.} & Pemanfaatan software & Ketepatan penggunaan fitur/software pendukung & 5,00 \\
\hline & & Rata-rata & 4,73 \\
\hline & & Kategori & Sangat Baik \\
\hline & & Persentase kelayakan & $94,6 \%$ \\
\hline
\end{tabular}

Berdasarkan Tabel 3, diketahui aspek tampilan memiliki skor penilaian terendah, terutama pada indikator kualitas media. Adapun koreksi dari ahli media terdiri dari : (1) header yang statis 
sehingga kurang menarik; (2) peletakan menu yang belum memudahkan pengguna; (3) link video yang sulit/lama untuk ditampilkan serta resolusi video yang terlalu kecil.

Tabel 4. Hasil Validasi Ahli Materi

\begin{tabular}{|c|c|c|c|}
\hline No. & Aspek Penilaian & Indikator & Skor \\
\hline & Materi & Kesesuaian materi dengan KD & 4,00 \\
\hline & Kebahasaan & Kebenaran struktur materi & 5,00 \\
\hline & & Kedalaman materi & 4,00 \\
\hline & Kebahasaan & Kebenaran penggunaan bahasa & 4,00 \\
\hline & & Kebenaran penulisan istilah dan tanda baca & 5,00 \\
\hline & Pedagogi (instruksional) & Ketepatan penyajian materi & 4,00 \\
\hline & & Kesesuaian media dengan materi & 5,00 \\
\hline & & Kualitas soal dan latihan & 4,00 \\
\hline & & Rata-rata & 4,39 \\
\hline & & Kategori & Sangat Baik \\
\hline & & Persentase Kelayakan & $87,8 \%$ \\
\hline
\end{tabular}

Terlihat pada Tabel 4 aspek yang memiliki nilai terendah yaitu aspek pedagogi (instruksional) terutama pada indikator kesesuaian media dengan materi yang terdiri dari: (1) gambar yang sebaiknya dibuat insert tambahan (zoomin) untuk memperjelas objek; (2) memperjelas keterangan topik pada link dokumen yang digunakan untuk mengerjakan tugas kelompok. Perbaikan aspek materi yaitu; (3) menambahkan indikator pencapaian KD dalam produk serta; (4) menambahkan informasi terkait keterkaitan konsep IPA dengan pembuatan kain sasirangan. kemudian, pada aspek kebahasaan yaitu mengenai; (5) perbaikan struktur kalimat materi yang belum sesuai EYD serta; (6) tanda baca yang masih keliru. Praktisi dalam hal ini guru IPA memberikan penilaian terhadap unsur media dan metarei MLI Sasirangan.

Tabel 5. Hasil Uji Kelayakan Praktisi

\begin{tabular}{clccc}
\hline No. & Penilaian & Skor rata-rata & Kategori & Persentase kelayakan \\
\hline 1. & Media & 4,53 & Sangat Baik & $90,60 \%$ \\
\hline 2. & Materi & 4,36 & Sangat Baik & $87,20 \%$ \\
\hline & Rata-rata & $\mathbf{4 , 4 5}$ & Sangat Baik & $\mathbf{8 9 , 0 0 \%}$ \\
\hline
\end{tabular}

Adapun beberapa komentar yang disampaikan oleh praktisi terdiri dari: (1) menambahkan penjelasan konsep-konsep IPA proses pembuatan kain sasirangan; (2) menambahkan indikator KD serta pada aspek pedagogi; (3) memperhatikan kalimat kata sambung dan kata depan pada kalimat yang sesuai EYD; (4) memperjelas deskripsi tugas kelompok.

Tabel 6. Hasil Uji Kelayakan Teman Sejawat (Akademisi)

\begin{tabular}{ccccc}
\hline No. & Penilaian & Skor rata-rata & Kategori & Persentase kelayakan \\
\hline 1. & Media & 4,80 & Sangat Baik & $96,00 \%$ \\
\hline 2. & Materi & 4,47 & Sangat Baik & $89,40 \%$ \\
\hline
\end{tabular}




\begin{tabular}{|c|c|c|}
\hline & Sangat Baik & $2,80 \%$ \\
\hline \multicolumn{3}{|c|}{$\begin{array}{l}\text { mengenai cara menanggulangi limbah sasirangan; (2) memperbaki tanda baca yang keliru; ( } 3 \\
\text { memperbaiki link web pada untuk mengelola informasi }\end{array}$} \\
\hline \multicolumn{3}{|c|}{$\begin{array}{l}\text { Uji keterbacaan diberikan kepada } 9 \text { orang peserta didik untuk menilai dan menanggap } \\
\text { gunaan produk MLI Sasirangan yang dinyatakan dalam } 5 \text { skala penilaian yang terdiri atas sanga } \\
\text { baik, cukup, kurang dan sangat kurang disertai pesan dan kesan terhadap penggunaan produk. }\end{array}$} \\
\hline \multicolumn{3}{|c|}{ Tabel 7. Hasil Uji Keterbacaan } \\
\hline No. & Pernyataan & Rata-rata skor \\
\hline 1. & Penulisan kalimat dan penggunaan bahasa yang digunakan & 4,13 \\
\hline & $\begin{array}{l}\text { Penyajian materi, nama-nama dan isi kegiatan explore pada Mobile learning IPA } \\
\text { (MLI) sasirangan }\end{array}$ & 4,50 \\
\hline & $\begin{array}{l}\text { Penggunaan media gambar, video, link website dan document untuk memperjelas } \\
\text { materi }\end{array}$ & 4,25 \\
\hline & Pemilihan warna gambar, icon dan background pada homepage. & 4,13 \\
\hline & Peletakan gambar, tulisan dan menu-menu pada MLI sasirangan. & 4,63 \\
\hline & Kualitas tampilan gambar, video link website serta pengunduhan file document. & 4,40 \\
\hline & Ukuran, jenis dan ketebalan huruf tulisan. & 4,50 \\
\hline & Penginstalan dan pengoperasian aplikasi. & 4,50 \\
\hline & Penggunaan software tambahan dalam aplikasi untuk membuka media. & 4,63 \\
\hline & $\begin{array}{r}\text { Rata-rata } \\
\text { Kategori } \\
\text { Persentase Kelayakan }\end{array}$ & $\begin{array}{l}\mathbf{4 , 4 7} \\
\text { Sangat Baik } \\
\mathbf{8 9 , 4 0 \%}\end{array}$ \\
\hline
\end{tabular}

Pada kolom kesan dan pesan pada angket yang diberikan terdapat beberapa tanggapan peserta didik disampaikan secara umum yaitu pengerjaan tugas online yang menarik dan pengetahuan baru tentang sasirangan serta dapat bermanfaat untuk lebih mengetahui tentang lingkungan sekitar.

\section{PEMBAHASAN}

Studi pendahuluan dilakukan untuk mengetahui tingkat kepemilikan smartphone peserta didik di sekolah yang memberikan izin kepada peserta didiknya membawa smartphone disertai fasilitas penunjang yang memadai untuk pembelajaran online. Seperti yang diungkapkan oleh Stosic (2015) yaitu terdapat dua hal yang perlu dipertimbangkan untuk menerapkan teknologi berbasis mobile yaitu kemampuan guru untuk menggunakannya serta sarana teknis sekolah yang memadai. Kepemilikan smartphone android peserta didik SMPN 1 Banjarmasin cukup tinggi sebesar 87\%. Selain itu peserta didik juga mengisi angket mengenai aktivitas penggunaan smartphone, diperoleh hasil yaitu aktivitas tertinggi sebesar 99,33\% peserta didik menggunakan smartphone untuk mengakses media sosial. Dengan demikian, SMPN 1 Banjarmasin dapat digunakan sebagai sekolah untuk menguji produk aplikasi berbasis android yang dikembangkan. 
Pertimbangan dalam pemilihan jenis LMS moodle karena moodle merupakan LMS yang open source (gratis), menyediakan alat komunikasi (chat dan forum diskusi), keterampilan belajar (kuis, tes, presentasi, penugasan), produktifitas (upload dan download) secara lengkap, serta lebih banyak digunakan oleh pengguna daripada jenis LMS open source lainnya. Pemilihan moodle sebagai LMS untuk mengembangkan aplikasi ini juga dipilih karena moodle pernah digunakan oleh guru IPA untuk memberikan ulangan harian kepada peserta didik melalui tes online di kelas IX.

Kualitas media Mobile Learning IPA (MLI) Sasirangan dinilai sangat baik dan layak untuk digunakan berdasarkan beberapa ahli, praktisi, akademisi serta dari respon peserta didik. MLI Sasirangan menyediakan beberapa fitur pembelajaran seperti gambar, video, tulisan (file doc dan $p d f$ ) dan link website. Tujuan dimasukkannnya media seperti tulisan dan link website dikarenakan agar peserta didik dapat menngunduh dan menyimpan file dan mempelajarinya saat sedangkan offline sedangkan link website sebagai penyedia Informasi-informasi terbaru tentang materi pelajaran baik untuk menjelaskan konsep, kasus pencemaran dan cara atau teknologi terbaru untuk mengatasi masalah pencemaran terutama mengenai penanggulangan limbah dan potensi dari bahan berbahaya dalam pembuatan kain sasirangan agar tidak mencemari ekosistem. Kelebihan dari beberapa fitur di atas seperti yang diungkapkan oleh Ekanayake dan Wishart (2014) bahwa gambar dan video pada perangkat mobile, terutama gambar yang diambil langsung melalui smartphone terkait kondisi lingkungan yang nyata dan dibawa ke dalam kelas dapat digunakan untuk menjelaskan konsep-konsep ilmiah terkait konteks yang telah diketahui peserta didik (lingkungan sekitar) untuk menanamkan pemahaman mereka tentang IPA. Hal ini juga yang disampaikan dalam MLI Sasirangan, proses pembuatan kain sasiragan disampaikan melalui gambar dalam tulisan dan video proses pembuatannya, sehingga peserta didik dapat langsung mengamati bagaimana potensi pencemaran dapat diidentifikasi. Selanjutnya, penggunaan gambar dan video juga dapat dugunakan untuk melakukan sebuah eksperimen ilmiah. Video terdapat dalam media pembelajaran online mengenai suatu prosedur ilmiah untuk mendapatkan suatu konsep IPA. Seperti yang terdapat pada MLI Sasirangan, terdapat video percobaan uji reaksi cacing tanah terhadap pupuk organik dan anorganik.

Berdasarkan komentar hasil penilaian disarankan untuk memperhatikan kualitas media terutama video yang dimuat memiliki resolusi yang kurang besar dan link video berjalan dengan lambat. Revisi dilakukan untuk dengan mengubah link video menggunakan $U R L$ dan langsung memuat link layar video di dalam kegiatan pembelajaran, sehingga akses yang dijalankan menjadi lebih cepat. Adapun dari segi konten, penilai menyarankan untuk meberikan informasi tambahan terkait teknologi terbaru untuk mengurangi dampak pewarna sintetis kain sasirangan yang berbahaya. Sehingga dimasukkan pula, beberapa hasil laporan penelitian dan video yang menggambarkan dan menjelaskan cara atau metode yang efektif untuk mengatasi masalah pencemaran dari pewarna kain sasirangan.

Keterfasilitasan MLI sasirangan untuk melatihkan keterampilan berpikir kritis terlihat pada matriks penggunaan media yang terdapat pada Tabel 2. Pembahasan isu permasalahan lingkungan dalam pembelajaran seperti dikembangkan dalam MLI Sasirangan dapat melatihkan keterampilan 
abad21 kepada peserta didik. Seperti yang dikemukakan oleh Monroe (2014) peningkatan pemikiran berpikir kritis peserta didik dengan mengangkat isu permasalahan lingkungan berguna untuk menfasilitasi kemampuan peserta didik untuk memanfaatkan dan mensintetis pengetahuan dan keterampilan dari berbagai sumber yang relevan untuk melakukan penyelidikan, menyelesaikan masalah yang mengarah pada tindakan sebagai pengetahuan atau informasi baru serta rasa tanggung jawab dan peduli terhadap lingkungan.

Tanggapan positif terhadap pembelajaran yang dikaitkan dengan isu permasalahan khususnya pada limbah pewarna kain sasirangan pada media berbasis online melalui angket keterbacaan pada uji coba terbatas sesuai dengan tujuannya diharapkan dengan mengetahui tentang sasirangan dan permasalahan dilingkungan sekitar dapat menumbuhkan rasa peduli dan tanggung jawab peserta didik terhadap lingkungan sekitar. Hal ini sesuai dengan pernyataan Kanene (2016) yang mengatakan bahwa presepsi (positif/negatif) terhadap lingkungan mempengaruhi rasa tanggung jawab terhadapnya yang akan menentukan sikap yang mereka pegang terhadap lingkungan melalui tindakan yang akan ditampilkan nantinya.

\section{Tahap Penyebarluasan}

Tahapan penyebarluasan yang telah dilakukan yaitu menyebarluaskan aplikasi MLI Sasirangan di SMPN 1 Banjarmasin dan melaporkan hasil pengembangan produk MLI sasirangan melalui penulisan artikel ilmiah.

\section{KESIMPULAN}

Adapun kesimpulan dari penelitian yang telah dilakukan yaitu:

Pertama; Produk Mobile Learning IPA Sasirangan (MLI Sasirangan) telah dikembangkan sebagai pemanfaatkan teknologi dalam pendidikan khususnya pada pembelajaran IPA SMP untuk menfasilitasi ketercapaian pembelajaran serta capaian kompetensi dari pendidikan nasional dan keterampilan abad 21. Melalui isu permasalahan pada lingkungan lokal yang diangkat diharapkan peserta didik akan memperoleh nilai-nilai keteladanan seperti sikap peduli dan bertanggung jawab terhadap lingkungan.

Kedua; Penilaian produk dilakukan oleh ahli dosen, guru mata pelajaran IPA dan mahasiswa pendidikan IPA serta uji coba terbatas kepada peserta didik diperoleh hasil bahwa kualitas produk sangat baik dan layak untuk digunakan dalam pembelajaran.

\section{DAFTAR PUSTAKA}

Cahyaningrum, \& Parmin. (2013). Pengembangan Media Monopoli Smart Science Seri Interaksi Makhluk Hidup dengan Lingkungan Berpendekatan Saintifik Pada Siswa SMP. Unnes Science Education Journal, 2(1), 852-857. Diambil dari http://journal.unnes.ac.id/sju/index.php/usej 
Darnita, K., I., Marhaeni, N., I., A., A., \& Candiasa, M. (2014). Pengaruh Penggunaan Bahan Ajar Online Terhadap Prestasi Belajar Tikom Dengan Kovariabel Aktivitas Belajar Siswa Kelas VIII Dwijendra Gianyar. e-Journal Pascasarjana Universitas Pendidikan Ganesha, 4, 1-10.

Djojosediro, W. (2010). Hakikat IPA dan Pembelajaran SD. Surabaya.

Ekanayake, S., \& Wishart, J. (2014). Mobile Phone Image and Video in Science Teching and Learning. Sri Lanka. https://doi.org/10.1080/17439884.2013.825628

Elkhateeb, M., Shehab, A., \& El-Bakry, H. (2019). Mobile Learning System for Egyptian Higher Education Using Agile-Based Approach. Hindawi: Education Research International, 2019, 13. https://doi.org/10.1155/2019/7531980

Ferreira, M. J., Moreira, F., Pereira, C. S., \& Durão, N. (2015). The Role of Mobile Technologies in The Teaching/Learning Process Improvement in Portugal. In ICERI Conference (hal. 46004610). Seville, Spain.

Gnana Singh, A. A., Leavline, E. J., \& Selvam, J. (2017). Mobile Application for mLearning. International Journal of Advance Research in Computer Science, 8(4), 313-317.

Holzer, A., \& Ondrus, J. (2011). Mobile App Development: Native or Web? Tematics and Informatics, 23(1), 22-31. Diambil dari http://www.janondrus.com/wpcontent/uploads/2008/05/WEB2012.pdf

Kanene, K. M. (2016). The Impact of Enviromental Education on The Enviromental Perceptions/Attitudes of Student in Selected Secondary School of Botswana. Europan Journal of Alternative Education Studies, 1(2), 36-54. https://doi.org/10.5281/zenodo.58777

Kasim, N. N. M., \& Khalid, F. (2016). Choosing the Right Learning Management System (LMS) for the Higher Education Institution Context: A Systematic Review. International Journal of Emerging Technologies in Learning, 11(6), 55-61. https://doi.org/10.3991/ijet.v11i06.5644

Kemdikbud. (2015). TIMSS Indografic. Jakarta.

Klimova, B. (2019). Impact of Mobile Learning on Students' Achievement Results. Education Sciences, 9(2), 90. https://doi.org/10.3390/educsci9020090

Kurniawati, A. A., Wahyuni, S., \& Putra, P. D. A. (2017). Utilizing of Comic and Jember's Local Wisdom as Integrated Science Learning Materials. International Journal of Social Science and Humanity, 7(1), 47-50. https://doi.org/10.18178/ijssh.2017.7.1.793

Ligi, B., \& Raja, W. D. (2017). Mobile Learning In Higher Education. International Journal of Research-Granthaalayah, 5(4), 1-6. https://doi.org/10.5281/zenodo.569363

Martono Kurniawan, T., \& Nurhayati Oky, D. (2014). Implementation of Android-Based Mobile Learning Application as a Flexible Learning Media. International Journal of Computer Science Issues, 11(3), 168-174.

Mohammed, F. (2017). Implementation of A Moodle Based Mobile Learning Environment. University Of Khartoum.

Monroe, M. (2014). The effects of environment-based education on students' critical thinking skills and disposition toward critical thinking. Environmental Education Research, (November 2004). https://doi.org/10.1080/1350462042000291038

Murwati, E. S., Kartika, I., \& M, G. B. (2012). Teknologi Proses Sasirangan dengan Variasi Teknik Jelujur. Dinamika Kerajinan dan Batik, 31, 35-40. 
Nurdiansyah, M. R. (2013). Telaah Hukum Terhadap Limbah Industri Kain Sasirangan Skala Kecil Studi Aspek Yuridis Industri Rumah Tangga Kampung Sasirangan Kelurahan Seberang Mesjid Kota Banjarmasin. Universitas Gadjah Mada, Yogyakarta.

Pernia, E. (2008). Strategy Framework for Promoting ICT Literacy in the Asia-Pacific Region. Bangkok: Unesco Bangkok. Diambil dari http://1 19.82.251.165:8080/xmlui/handle/123456789/34

Priya, S. (2018). Mahir Praktikum Biologi. Yogyakarta: DEEPUBLISH.

Rachman, H., A., Adina, A., \& Primanadini, A. (2017). Penentuan Chemical Oxygen Demand (COD) pada Air Sungai Martapura Akibat Limbah Industri Tekstil Sasirangan. In Seminar Nasional dan Presentasi Ilmiah Perkembangan Terapi Obat Herbal pada Penyakit Degeneratif (Vol. 1, hal. 32-38).

Stosic, L. (2015). The Importance of Educational Technology In Teaching. International Journal of Cognitive Research in Science Engineering and Education (IJCRSEE), 3(1), 111-114.

Sulistyorini, I. S., Edwin, M., \& Arung, A. S. (2017). Analisis Kualitas Air Pada Sumber Mata Air Di Kecamatan Karangan Dan Kaliorang Kabupaten Kutai Timur. Jurnal Hutan Tropis, 4(1), 64. https://doi.org/10.20527/jht.v4i1.2883

Tan, J. P., Choo, S. S., Kang, T., \& Liem, G. A. D. (2017). Educating for Twenty-First Century Competencies and Future-Ready Learners : Research Perspectives from Singapore. Asia Pacific Journal of Education, 8791, 1-11. https://doi.org/10.1080/02188791.2017.1405475

Tihiagarajan, \& Semmel. (1974). Instructional Development for Training Teachers of Exceptional Children: A Sourcebook. Indiana: Indiana University Bloomington.

Wallet, P. (2014). Information and Communication Technology (ICT) in Education in Asia: A comparative analysis of ICT integration and e-readiness in schools across Asia. Information paper; 22. Canada: UNESCO Institute for Statistics. https://doi.org/10.15220/978-92-9189-1481 -en

Widoyoko, P. E. (2009). Evaluasi Program Pembelajaran. Yogyakarta: Pustaka Pelajar. 